THE DIFFERENTIATED EFFECTS OF CSR ACTIONS IN THE SERVICE INDUSTRY

\author{
Ana B. Casado \\ Juan L. Nicolau \\ Felipe Ruiz \\ Ricardo Sellers \\ Dept. of Marketing \\ Faculty of Economics \\ University of Alicante \\ PO Box 99 \\ 03080 Alicante \\ SPAIN
}




\title{
THE DIFFERENTIATED EFFECTS OF CSR ACTIONS IN THE SERVICE INDUSTRY
}

\begin{abstract}
Corporate Social Responsibility (CSR) is becoming a common strategy within medium and large companies, which explains the growing number of studies and disciplines focusing on it. One stream of research examines the effects of CSR on a firm's performance, such as its market value, suggesting that the financial performance outcomes of responsible corporate behavior may vary depending on firm-specific and industry-related factors. This study attempts to explain why the impact of CSR initiatives may be different and/or more important in service firms compared to product-based companies. To address this question, we analyze all the 248 companies that have ever traded on the Spanish Stock Market between 1990 and 2007. The results show that CSR activities have a positive impact on firm performance that is higher for service firms than for product-based firms. As for practical implications, these findings suggest that CSR may be an especially valuable tool for differentiation in the service context.
\end{abstract}

\section{Keywords}

corporate social responsibility, service firms, market value, event study 


\section{Introduction}

Corporate Social Responsibility (CSR) has received considerable scholarly attention over the decades, becoming an integral part of business practice (Mattila and Hanks, 2012). Behind the expansion of CSR activities, we can find many reasons. For example, the growing pressure from civil society actors, such as international organizations, NGOs, or civil society groups, that has pressed companies to make them more socially and environmentally responsible (Scherer and Palazzo, 2011; Zhang et al., 2012). But also the firm's profit strategy has pushed it to be socially responsible because of an anticipated benefit (e.g., reputation enhancement, recruitment of high-quality workers, differentiated products that extract a premium) from these actions (Husted and Salazar, 2006; McWilliams and Siegel, 2000; Waddock and Graves, 1997). Accordingly, this topic has received considerable attention in the marketing and management literature. One primary stream of research has focused on the effects of CSR on the financial outcomes of the firm, such as its market value, although the results of these studies remain mixed (Griffin and Mahon, 1997; Orlitzky et al., 2003). One of the explanations offered for these inconsistent results is that much of the research does not consider the influence of other related variables but only CSR (Barnett and Salomon, 2006). There have been claims to introduce more variables that relate to industry, culture, national systems, and context into this genre of research (e.g., Aguilera et al. 2007; Goll and Rasheed, 2004; Salzmann et al., 2005; Simpson and Kohers, 2002). More specifically, Arendt and Brettel (2010), and Halme and Laurila (2009) argued that the financial performance outcomes of responsible corporate behavior might vary depending on firm-specific and industry-related factors. However, studies on CSR have mostly focused on the product-based industry (e.g., Sen et al., 2006) rather than the service industry (Kang et al., 2010; Vlachos et al., 2009).

This article proposes that CSR is likely to play a particularly important role in services selling contexts. We analyze the shareholders' evaluation of socially responsible service companies by looking at the announcements of intended CSR actions. We theorize that these announcements affect more positively shareholder value in service firms compared to good firms through a direct and an indirect way. The direct way refers to the investors' responses to the announcements of intended CSR actions. The indirect way refers to the effect that marketing strategies such as CSR activities have on consumers -or the demand 
route- (Kalaignamam et al., 2013). As we will argue, service-inherent characteristics make it difficult for investors and customers to evaluate service firms in advance and force them to look for information regarding the service company and the service quality in order to reduce the perceived risk. Companies' CSR initiatives, one of the mechanisms that may be used to infer service quality, may constitute a valuable signal of the firm's reliability and commitment to quality and honesty. According to signaling theory, investors would respond to announcements of intended CSR actions by buying stock if they foresee potential or approve (Asquith and Mullins, 1986). Although they are assumed to be rational decision makers, they often evaluate information using cues and heuristics (Wiles, 2007: p. 19). Thus, since service firms are harder than product firms to evaluate, investors may value their CSR efforts higher because they contribute to reduce their perceived risk.

Additionally, investors' responses also reflect their perceptions (heuristics) of the firm's ability to strengthen its brand equity and generate cash flows through such marketing activities and the investment's perceived consumer impact (Lane and Jacobson, 1995). Service firms' investors thus, value their stock prices also indirectly, through the effect that marketing strategies such as CSR actions' announcements have on consumers -or the demand route- (Kalaignamam et al., 2013); i.e., an increase in satisfaction, loyalty and, ultimately, profit and market value (Luo and Bhattacharya, 2006).

Our research contributes to the extant research on CSR and firm performance in that we explain why this relationship may be different and/or more important (stronger) for service versus good firms. To this end, this paper uses event study methodology to examine how financial markets respond to the news on a company that implements a CSR action, which reflects whether investors 'care' about CSR. We analyze all the 248 companies that have ever traded on the Spanish Stock Market between 1990 and 2007. The results show that CSR announcements are associated with positive excess returns that are higher in service companies compared to product-based companies.

\section{Theoretical foundations}

CSR in the Study Context

CSR conceptualizations have been influenced by different theories, including agency theory, institutional theory, the resource-based view of the firm, stakeholder theory or 
stewardship theory (Lindgreen and Swaen, 2010). However, as noted by Lankoski (2009a, p.208), stakeholder theory has gained wide popularity in explaining the relationship between corporate responsibility and economic performance (e.g., Orlitzky et al., 2003). Stakeholder theory sustains the idea that firms do not have responsibilities towards society in general, but rather they should only be concerned about groups -i.e. stakeholders- that may be affected by their activity (Clarkson, 1995). Thus, stakeholders are defined as "any group or individual who can affect or is affected by the achievement of the organization's objectives” (Freeman, 1984, p. 46). Additionally, stakeholders have been grouped in many ways. For example, Clarkson (1995) distinguishes between primary stakeholders (employees, shareholders, customers, suppliers, the government and the community in which the firm operates) and secondary stakeholders (the media and interest groups), whereas Lankoski (2009a) divides them into market stakeholders (those who engage in market exchanges with the firm) and nonmarket stakeholders (those who do not engage in market exchanges with the firm but still have some interaction with it). In this paper, we focus on a primary-market stakeholder group, the shareholders, by analyzing their assessment of socially responsible companies and the effect of the service vs. good character of the firm.

Therefore, given that the specific focus of this study, CSR is defined as "management of stakeholder concern for responsible and irresponsible acts related to environmental, ethical and social phenomena in a way that creates corporate benefit" (Vaaland et al., 2008, p.931). This definition highlights the multidimensional character of the CSR strategy, which will be also examined, considering it as a set of heterogeneous activities rather than one monolithic measure, in line with several authors (e.g., Bhattacharya and Sen, 2004; Carroll, 1979, 1991a; Kotler and Lee, 2005).

\section{Impact of CSR on Financial Performance}

The relationship between CSR and financial performance has been alternatively hypothesized to be positive, negative, and neutral (Simpson and Kohers, 2002). The negative relationship is explained by the thesis that high investment in CSR would result in additional costs that would reduce profits and shareholder wealth (Hull and Rothenberg, 2008). Empirical evidence demonstrates that CSR investment can be destructive to 
financial performance when it passes a certain level (Wang et al., 2008). The neutral relationship is explained by the complexity of both the firm and the society, which makes it difficult to establish a simple and direct link between CSR and firm performance (Margolis and Walsh, 2003; Ullmann, 1985; Waddock and Graves, 1997). This neutral relationship is also supported by McWiliams and Siegel $(2000,2001)$ on the basis of the supply and demand theory of the firm. Finally, regarding the positive relationship, some authors suggest that the costs of CSR activities are minimal compared to the potential benefits to the firm (e.g., Pava and Krausz, 1996). Higher CSR can result in higher ability to attract and retain quality employees (thus reducing the probability of labor problems) (Andreassen and Lanseng, 2010; Gouthier and Rhein, 2011; Lings and Greenley, 2010) and in more positive customer attitudes toward the firm and the purchase of its products (e.g., Du et al., 2007). Further, CSR activities may improve a firm's reputation (e.g., Vilanova et al., 2009) and its relationships with stakeholders, and these improved relationships may also be translated into economic benefits (Bhattacharya and Sen, 2004).

As stated above, empirical research has produced mixed results. However, the majority of these studies on the relationship between CSR and firm performance document a positive relationship. As noted by Halme and Laurila (2009), and Stuebs and Sun (2009), a recent literature review (Beurden and Gössling, 2008), two meta-analyses (Margolis and Walsh, 2003; Orlitzky et al., 2003), and several recent studies (e.g., Brammer and Millington, 2008) support the positive link. Additionally, most of the studies have reached a common conclusion that CSR behavior contributes to a firm's long-term sustainability and growth (Taneja et al., 2011). Therefore, although there is no straightforward evidence of the relationship between CSR and financial performance, we expect that CSR activities undertaken by firms will positively affect their performance.

\section{CSR Effect on Performance in Service Firms vs. Goods Firms}

After discussing the relationship between CSR and firm performance, our goal is to examine the differential effects of CSR for goods versus services firms. In developing our prediction that CSR effect on performance is higher for services firms than for goods firms, we turn to the literature in financial economics and services marketing. In line with the efficient market hypothesis, which asserts that the stock price reflects all public information 
about the firm, new information such as CSR actions should change the price of a stock (Fama et al., 1969). According to signaling theory, investors would respond to firms' announcements by buying stock if they foresee potential or approve (Asquith and Mullins, 1986). However, investors' responses also reflect their perceptions of the firm's ability to strengthen its brand equity and generate cash flows through such marketing activities. Investors' judgments of the value of a firm's marketing investment depend on the investment's perceived consumer impact (Lane and Jacobson, 1995). We propose that service firms' investors react more positively to CSR activities compared to product firms' investors because of the specific nature of the services. Although they are assumed to be rational decision makers (Colisk cited in Wiles, 2007: p. 19), they often evaluate information using cues and heuristics (Stracca cited in Wiles, 2007: p. 19). Thus, since services' firms are harder than products' firms to evaluate, investors may value their CSR efforts higher because they contribute to reduce their perceived risk. In fact, previous research has shown that announcements of customer service strategies are rewarded by investors, suggesting that customer service is one of the more effective ways for firms to create shareholder wealth (Wiles, 2007).

Additionally, service firms' investors value their stock prices not only directly but also indirectly, through the effect that marketing strategies such as CSR actions' announcements have on consumers -or the demand route- (Kalaignamam et al., 2013). While manufactured goods tend to be more easily checked for conformance with objective quality standards, service customers often face great variability in service outcomes (Zeithaml, 1981). Prior to the service encounter, the customer forms expectations about the forthcoming experience using a number of intrinsic and extrinsic cues that give an indication of the likely performance standards. The information obtained in this pre-purchase stage is especially relevant in the service industry because of service-inherent characteristics-intangibility, inseparability, heterogeneity, and perishability (Grönroos, 1994; Zeithaml and Bitner, 2000), factors that make it difficult to anticipate the quality of the service until the service is tried and that lead customers to perceive service decisions as risky (Coulter and Coulter, 2002; Murray and Schlacter, 1990). In order to reduce the perceived risk and choose the best firm, customers look for information regarding the service company and its true characteristics (Bergen et al., 1992). At the same time, service firms send signals to the 
market so that customers can make inferences about them and the quality they offer. All these work together to generate an information asymmetry context.

Information asymmetry issues have been analyzed by agency and signaling theories (e.g., Mishra et al., 1998). Focusing on the service sector, San Martin and Camarero (2005) argued that, in terms of agency theory, the customer's lack of information raises an “adverse selection” problem (an information asymmetry problem), which means that it is difficult for a customer to set the true quality of different services (Bergen et al., 1992; Eisenhardt, 1989; Mishra et al., 1998; Singh and Sirdeshmukh, 2000). Following signaling theory, the partners in an exchange have different information, which affects their transactions and relationships. Information regarding quality may constitute an important cue (signal) for both customers and service firms (Kirmani and Rao, 2000; Rao et al., 1999), and it is closely related to the firm's vulnerability to consumer sanctions (e.g., reputation loss and/or market value decrease) in case the promised quality is false (San Martin and Camarero, 2005).

Among all the mechanisms consumers may use to infer service quality, an individual may rely on announcements of CSR actions in order to reduce uncertainty, as s/he may reasonably think that taking care of society implicitly means taking care of customers (Nicolau, 2008). Previous research suggests that consumers are more willing to patronize establishments and corporations that are perceived as socially responsible (Mackey et al., 2007). Consumers' perception of socially responsible behavior has been shown to have an influence on their valuation of the service and the perceived quality (García de los Salmones et al., 2005). CSR activities also help to build company reputation (Barnett and Hoffman, 2008), which also indicates a company's involvement in providing quality services/products. Customers often use corporate reputation to assess products, with positive reputation resulting in higher perceptions of product/service quality (Jacoby et al., 1971; Shapiro, 1982). In the minds of some consumers, CSR is a signal of honesty and reliability, and a reliable and honest firm is believed to produce better products (Siegel and Vitaliano, 2007).

Siegel and Vitaliano (2007) found that firms selling experience goods (i.e., products whose characteristics cannot be verified before buying or using them), and experience and credence services are more likely to engage in CSR than those selling search goods (i.e., 
products whose characteristics can be identified before buying). The authors showed that the difference in the intensity of CSR involvement across types of goods is explained by the consumers' perception of a firm's involvement in CSR as a valuable signal of the firm's reliability and its commitment to quality and honesty. In this regard, the research findings state that a positive impact of CSR on performance is generally found in consumer industries and especially for experience goods and credence services (Baron et al., 2009; Hoepner et al., 2010; Siegel and Vitaliano, 2007). Previous research supports this assumption (e.g., Calabrese and Lancioni, 2008; García de los Salmones et al., 2005; Maignan and Ferrell, 2001; Sureshchandar et al., 2001, 2002). Maignan and Ferrell (2001) theoretically proposed that CSR has a positive influence on consumers, in particular, on their valuation of a firm's products. Sureshchandar et al. (2001, 2002) considered that the firm's ethical behavior transmits trust to users and influences their evaluation of the overall quality of the service received. García de los Salmones et al. (2005) found that a firm's socially responsible behavior has a direct and positive influence on the overall valuation of its service (measured by means of technical quality, functional quality and perceived value) by users of mobile telephone services. Finally, Calabrese and Lancioni (2008) argued that service corporations need to be more proactive, anticipating customers' needs and preferences, compared to other sectors and suggested that CSR activities have more positive effects in service companies given the high degree of similarity among these companies, their services, and the social and environmental initiatives (Becker-Olsen et al., 2006). Therefore, the reduction of more prevalent information asymmetry should have a greater effect on reputation in services compared to manufacturers; this reputation, in turn, should bring about a higher firm value. Remember that positive attitudes derived from CSR are claimed to lead to higher expectations of sales; if this is to happen in any context per se, further enhancement of expectations should appear when existing information asymmetries are diminished.

In sum, we assume that the CSR events do carry more information and increase higher service firms' investor awareness compared to products firms' investors, because they make more information available to investors and reduce the information asymmetry problems (information cost hypothesis). These effects have a double source of origin, directly -through investors' evaluation- and indirectly -through consumers' reactions-. 
Consequently, we propose that:

Research hypothesis: CSR activities undertaken will have a more positive influence on market value in service firms than in non-service companies.

\section{Method}

The Event Study Technique

We based the analysis on the event study technique and on the premises that stock markets are efficient and that a company's share price reflects its CSR strategy (see Johnston (2007) for a review of the application of event studies in marketing). In an efficient stock market, the share prices reflect all the available information on a company, and we assume that tangible and intangible markets are equally efficient. In fact, any information received by the market (e.g., on CSR activities) will be instantly incorporated into the share price. Likewise, any change in a company's share price will reflect, without bias, alterations to its future cash flows. Therefore, the introduction of new information on CSR activities allows an examination of share price behavior to explicitly analyze the underlying change in unbiased market predictions of future returns on the said social activity.

The purpose of the event study method is to estimate the excess returns generated by a sample of unanticipated events -the basic hypothesis is that abnormal returns reflect the stock market reaction to the arrival of new information- defining each event as an announcement of CSR activities. The event study measures the impact of unanticipated events on share prices, being based on the estimation of a market model for each company event and on the posterior calculation of abnormal returns.

\section{Data Collection}

The event study technique is based on the following data collection process developed by McWilliams and Siegel (1997). In the first stage, starting with all the 248 companies that have ever traded on the Spanish Stock Market between 1990 and 2007, we detected those companies that carried out CSR activities. To this end, we carried out a search of the Factiva database (which provides information on headlines and news items published in different newspapers with international and national coverage, as well as those with general and/or specialized content) using a combination of keywords, such as "company name”, 
“CSR”, “social action”, “philanthropy”, “sustainability”, “good corporate governance”, “informative transparency”, “disable”, “ethics”, “technological innovation”, “sponsorship”, "environment", and many other variants of these. In unclear cases, we looked at the full news item in the corresponding newspaper. This involved reviewing around 28,300 news items, from which we identified 2,246 CSR initiatives. The event day was defined as the first day on which the news was divulged in any of the publications included in the database.

In the second stage, we selected the length $k$ of the event window to test for any abnormal behavior in company share returns. To be precise, we considered the five days before and after $(-5 ;+5)$ the announcement date. Although it was expected that most of the information on CSR activities would be quickly incorporated into share prices, it occasionally either leaked out before any formal publication or was held back. Note that the choice of the length of the event window is a trade-off: it should be long enough so that any significant impact is detected, but short enough so that the effect of confounding effects is kept at a minimum. In short, a 3-day window (such as $(-1,+1)$ ) could fail to identify potential abnormal returns occurring two days before or after the event day, and a 41-day window (e.g., $(-20,+20)$ ) would not make it easy to "clean" that period and analyze it free of another information different from CSR announcements that could affect the firm's value. Even though we could have used a longer window length because, as indicated below, our sample size is quite large, it would not be accurate to expect that the press is currently echoing a specific news item beyond five days (Brown and Warner, 1985).

In the third stage, we eliminated announcements of CSR actions that were very close in time to one another (those appearing within the 5-day event window); otherwise, it would not have been possible to determine which of them, if any, was generating abnormal returns. The resulting sample consisted of 1,394 announcements.

In the fourth stage, we discarded any announcements whose event windows published notices such as "takeover bids", "share offers", "profit announcements", “dividend declarations”, “splits”, “complaints”, “claims”, “quality awards”, “trade union actions”, “mergers”, "labor disputes”, “dismissals”, “government contracts”, “court cases”, and "introduction of new products", among others. This was to facilitate the exclusive measurement of the effect of the CSR action and to eliminate the possibility of including 
other effects. Thus, the sample was further reduced from 1,394 to 583 announcements. These announcements referred to "environmental issues," "responsible labor relationships," “social action,” "good corporate governance," “informative transparency," and “philanthropic sponsorship,” in line with Olcese’s (2007) proposal. It is important to stress the fact that the process of data collection guaranteed that these news items were released during the study period. These 583 come from 117 firms with an average number of announcements per firm of 4.59 (see Table 1).

\section{Take in Table 1}

In the fifth stage, we collected data on market measures of performance, which allowed us to consider the risk supported by the firm and the capitalized value (expectations) of the benefits of CSR activities, as well as to minimize the distortions resulting from tax laws and accounting standards. These daily returns were adjusted for dividends, subscription rights, and splits. The returns on the share price of a company $i$ on day $t\left(R_{i t}\right)$ was expressed as (Sharpe, 1963, 1964): $R_{i t}=\alpha_{i}+\beta_{i} R_{m t}+\varepsilon_{i t}$ (1), where $R_{m t}=$ returns on the market portfolio on day $t$ (this study uses the IBEX 35, a representative index of the Spanish Stock Market, as a substitute variable for the true returns on the market; the information was obtained from the Stock Exchange Society), $\alpha_{i}=$ returns on the shares of company $i$ independent of those of the market, $\beta_{i}=$ sensitivity of returns on share $i$ to variations in market returns, and $\varepsilon_{i t}=$ error term. The estimation of equation (1) allowed us to calculate the daily abnormal returns (AR) for a company $i$ announcement (2): $A R_{i t}=R_{i t}\left(a_{i}+b_{i} R_{m t}\right)$, where $a_{i}$ and $b_{i}$ are the estimations of the regressions (1) for period $T$ before the event. It is important to note the characteristic kurtosis and heteroskedasticity in the error term of equation (1). For this reason, this study estimated an autoregressive conditional heteroskedasticity model (Bollerslev, 1986), GARCH (1,1), the main purpose of which was to model the conditional variance of the returns. Such models distinguish between unconditional variance, which is constant and stationary, and conditional variance, which is modified by the available information. Thus, the returns defined by means of this specification are obtained by assuming that ${ }_{i t}=h_{i t}{ }^{1 / 2}{ }_{i t}$ and ${ }_{i t} / i t-1, i t-2, \ldots \mathrm{N}\left(0, h_{i t}\right)$, where ${ }_{i t}$ are i.i.d. with $\mathrm{E}\left({ }_{i t}\right)=0$ and $\mathrm{E}\left({ }_{i t}^{2}\right)=1$. In this context, $h_{i t}$ is the conditional variance and represented as $h_{i t}=c_{i}+{ }_{i}{ }_{i t-1}{ }^{+}{ }_{i} h_{i t-1}$, where $c_{i}$, $i$, and ${ }_{i}$ are the parameters to be estimated. 


\section{Testing Abnormal Returns}

Abnormal returns represent those obtained by a company once investors have adjusted for normal returns; the return on shares is adjusted by subtracting the expected returns from the actual returns so that any significant difference is considered abnormal.

To analyze the effect of a company's announcements of CSR activities on its share price, this article tested the significance of the average abnormal returns for $N$ company announcements on the event day $(\mathrm{t}=0)$ using Brown and Warner's (1980) parametric test (which is the traditional test) and Boehmer et al. (1991) parametric test (which considers event-induced variance changes).

To examine the potentially different effect of CSR on service and goods firms, we conduct a regression analysis, in which the dependent variable is the abnormal returns and the independent variables are the service character of the firm, measured by a dummy variable, and two control variables: type of CSR activity and firm size.

Type of CSR activity. As stated above, previous research on the relationship between CSR and firm performance evidence contradictory findings, to a certain extent because CSR has been treated as a global strategy without including in the analyses the many different ways it is practiced. From the original classification established by Carroll (1991a): economic, legal, ethical, and philanthropic responsibilities, attempts to categorize the phenomenon of CSR have led to multiple typologies (e.g., Bhattacharya and Sen, 2004; Kotler and Lee, 2005). In a recent review, Peloza and Shang (2011) categorize CSR types and conclude that not all the categories are viewed as equally positive or positive at all by stakeholders. In fact, CSR may encompass a wide range of programs and policies, e.g., protection of human rights, safety in the workplace, eco-efficiency innovations, and community development (Baughn et al., 2007), reflecting variations across companies and their relationships with their stakeholders. Empirical research on the impact of two or more components of CSR activities on financial performance reports different findings (e.g., Barnett and Salomon, 2006; Berman et al., 1999; Bird et al., 2007; Husted, 2000; Lankoski, 2009b; Pava and Krausz, 1996). Continuing this recent trend, which considers CSR as a set of heterogeneous firm activities rather than one monolithic measure, we control for the existence of performance differences when companies implement different types of CSR activities. Accordingly, and starting from the Valand et al.'s (2008) definition, our research 
goes a step further by using the Olcese's (2007) proposal. This is a wider typology of CSR activities in order to deal with the heterogeneous nature of this strategy with more detail, but also linked to the three dimensional perspectives (environmental, social, and ethical) considered in Valand et al. (2008) definition.

Thus, this paper considers the following activities: “environment” (164 announcements), which considers all the activities related to the environment; "responsible labor relationships” (26), “social action” (119), and “philanthropic sponsorship” (167), which are linked to the social dimension perspective; and, "good corporate governance" (67), and "informative transparency" (40), which are linked to the ethical conduct in business practice. Dummy variables are used and "philanthropic sponsorship" is taken as the base reference in the regression analysis.

Firm size. The size of a firm reflects, to a certain extent, their available resources and, thus, large firms are more able to implement CSR actions (Lee and Chen, 2009), being more likely to have economies of scope and scale (Lieberman and Montgomery, 1988). However, “routine rigidity” (Dickson, 1992) emerges in larger organizations, which makes it less easy to take advantage of market opportunities. Actually, Lee and Chen (2009), in the context of new product introductions, find a negative effect of size on shareholder value, as investors evaluate more optimistically smaller firms which do not have the "layers of bureaucracy" within the organization; let alone the so-called "green backlash" large service companies can suffer derived from their lack of credibility (Chun and Giebelhausen, 2012). To measure the size of the firm we use the logarithm of the firm's assets.

\section{Results}

Table 2 shows the estimation of the average abnormal returns in several event windows of the 583 announcements (of which 288 belong to service companies). We have tested these different windows strategically, so that we make sure the analysis covers the whole range of days, starting from $(-5,-4),(-5,-3), \ldots$ so that the pre-announcement period is examined, then we focus on the full-length window $(-5,+5)$, and finally we analyze the postannouncement windows $(+1,+5),(+2,+5)$ and so on. The results obtained demonstrate that, on average, CSR announcements are associated with positive excess returns on the postevent days, thus showing, as expected, that CSR activities undertaken by firms will positively affect their performance. In particular, both tests -Brown and Warner, and 
Boehmer et al.,- present significant positive values over the windows $(+1,+5),(+2,+5)$, $(+3,+5)$, and $(+4,+5)$. This means that, on average, firms announcing CSR activities undergo a gain between $0.18 \%$ and $0.26 \%$ on the five days after the announcement. Note, however, that no reaction appears to exist before the announcement day. This outcome implies that there does not seem to be any significant information leakage prior to the information becoming publicly available, or if there happens to be, investors seem to wait for the official announcement before reacting. The possibility of "greenwashing” (i.e., claiming to be social responsible without implementing anything) can exist, so they do not react until the CSR action is formally announced.

\section{Take in Table 2}

To test our research hypothesis, which states that CSR activities undertaken will have a more positive influence on market value in service firms than in non-service companies, we perform a regression analysis (see Table 4). Prior to this analysis, we look at the correlations between the two independent variables to check for collinearity. Table 3 shows that no jeopardizing high values exist and, even more insightful to this point, this absence of collinearity is further ensured by the low figures of the variance inflation factors (VIF) for each coefficient, which fall between 1.09 and 1.49, well below the cut off figure of 10 recommended by Neter et al. (1985).

\section{Take in Table 3}

\section{Take in Table 4}

Second row in Table 4 shows that the effect of CSR in the service firms is significant at 0.05, confirming our key hypothesis that the enhancement of reputation via CSR brings about higher returns in service companies.

Regarding the control variables, we find that, while firm size is not significant, the CSR types show significant effects for actions related to the environment (environment dimension), responsible labor relationships (social dimension), and good corporate governance (ethic dimension). In order to delve into these influences, we analyze potential differentiated effects of CSR types on service and non-service firms. Table 5 shows the results of $t$-tests conducted for each CSR activity, which indicate greater effects for service than non-service firms in the same CSR types that were found significant in the previous regression analysis, namely, “environment”, “responsible labor relationships” and "good 
corporate governance". No differences are detected in the CSR types "social action", "informative transparency" and "philanthropic sponsorship", in line with the regression results.

\section{Take in Table 5}

\section{Discussion}

\section{Theoretical and Managerial Implications}

Previous research on the effects of CSR on financial performance mostly focused on the product-based industry (Kang et al., 2010; Vlachos et al., 2009). We investigate whether and how this relationship may be particularly important in the service-selling context. Prior work also noted that different types of CSR activities have different effects on firm value (Barnett and Salomon, 2006; Bird et al., 2007; Lankoski, 2009b; Peloza and Shang, 2011). Thus, we investigate further whether and how these differentiated effects apply to service firms compared to product-based firms.

The current research shows that CSR activities have a positive impact on firm performance that is higher for service firms than for product-based firms. This finding extends the extant literature on the effects of CSR on financial performance by showing that CSR plays a particularly important role in service-selling contexts. Firms' CSR initiatives are used as a positive signal of the firm's reliability and its commitment to quality and honesty (Siegel and Vitaliano, 2007). Accordingly, service firms actively involved in CSR activities should emphasize their responsible behavior as a mechanism to differentiate themselves from competitors (Porter and Kramer, 2006). This strategy depends largely on customers' and also investors' trust in a firm's real (responsible) intentions and behaviors. In this sense, recent research has demonstrated that CSR offers protection for CSR-related negative information in a service-selling context, which extends to negative information related to firms' core service offerings when consumers are novices (Eisingerich et al., 2011; Godfrey et al., 2009). This result supports the above proposed strategy in which a service firm should actively communicate socially responsible behaviors to its stakeholders. In fact, research findings indicate that many companies do not effectively communicate their CSR activities to their stakeholders (Du et al., 2007; Sen et al., 2006), which constitutes a critical impediment for these companies in maximizing the 
business benefits of their CSR activities (Du et al., 2010).

As for practical implications, the current financial and economic crisis increases distrust among customers and provides additional motivation for service firms to focus on CSR activities. The findings suggest that service firms are likely to gain from focusing on some CSR activities, such as “environment” (with its critical effects on society’s future wellbeing), “responsible labor relationships” (aimed at internal stakeholders -employees-, which are especially important in the service context (Bitner et al., 1990)) or "good corporate governance" (of great concern for all stakeholders, but they will probably be more relevant and visible to customers and investors).

\section{Limitations and Further Research}

The following limitations were identified in the current research. First, in examining the hypothesis regarding differences between service and product firms, we did not differentiate within sectors of the same kind. As such, researchers may aim to include subsectors in future studies to see if the proposed hypotheses apply to them or whether some differences arise regarding specific industry/sector characteristics. Second, in assessing the effect of (different) CSR activities on financial performance in service firms, the present study did not include the volume of CSR activities and the time it took the firm/(sub)sector to carry them out. Future research may examine how the relationship between CSR and performance in service contexts could change based on the volume of CSR activities implemented and the period of time it took the firm to practice the CSR behavior (firm's CSR expertise). Third, it may be worthwhile to examine the interaction effects of different CSR activities to help managers to find the best CSR mix. Fourth, we focused on financial performance (shareholders' perspective), but we did not consider other stakeholders. As such, a promising avenue for future research is to consider more perspectives together by examining whether firms' CSR activities affect real consumer behavior or employees' commitment and productivity. For example, to what extent can CSR activities enhance employees' commitment and customers' perceived reputation of service firms? Are these effects different for different types of service organizations?. Fifth, we have focused on intentions rather than real actions. Therefore, it would be relevant, first, to observe whether realization announcements perform just like intention announcements 
do; and second, to examine whether "greenwashing" strategies exist and, if they do, whether they are penalized by the different stakeholders. As noted by Du et al. (2010), this stream of research could include questions regarding CSR communication (i.e., what and where to communicate) to deal with potential skepticism. Lastly, we examined the effect of CSR on service firms' financial performance in the Spanish stock market. To afford greater confidence in the generalizability of our results, we encourage future research to explore these relationships in different country contexts. 


\section{References}

Aguilera, R.V., Rupp, D.E., Williams, C.A. and Ganapathi, J. (2007), “Putting the S back in corporate social responsibility: A multilevel theory of social change in organizations”, Academy of Management Review, Vol. 32 No. 3, pp. 836-863.

Andreassen, T.W. and Lanseng, E.J. (2010), "Service differentiation: A self-image congruency perspective on brand building in the labor market”, Journal of Service Management, Vol. 21 No. 2 pp. 212-236.

Arendt, S. and Brettel, M. (2010), "Understanding the influence of corporate social responsibility on corporate identity, image, and firm performance”, Management Decision, Vol. 48 No. 10, pp. 1469-1492.

Barnett, M.L. and Hoffman, A.J. (2008), “Beyond corporate reputation: Managing reputational interdependence”, Corporate Reputation Review, Vol. 11 No. 1, pp. 1-9.

Barnett, M.L. and Salomon, R.M. (2006), "Beyond dichotomy: The curvilinear relationship between social responsibility and financial performance”, Strategic Management Journal, Vol. 27 No. 11, pp. 1101-1122.

Barone, M.J., Miyazaki, A.D. and Taylor, K.A. (2000), “The influence of cause-related marketing on consumer choice: Does one good turn deserve another?”, Journal of the Academy of Marketing Science, Vol. 28 No. 2, pp. 248-263.

Baughn, C.C., Bodie, N.L. and McIntosh, J.C. (2007), “Corporate social and environmental responsibility in Asian countries and other geographical regions”, Corporate Social Responsibility and Environmental Management, Vol. 14 No. 4, pp. 189-205.

Becker-Olsen, K.L., Cudmore, A. and Hill, R.P. (2006), "The impact of perceived corporate social responsibility on consumer behavior”, Journal of Business Research, Vol. 59, pp. 46-53.

Bergen, M., Dutta, S. and Walker, O.C.Jr. (1992), “Agency relationships in marketing: A review of the implications and applications of agency and related theories”, Journal of Marketing, Vol. 56 No. July, pp. 1-24.

Berman, S.L., Wicks, A.C., Kotha, S. and Jones, T.M. (1999), “Does stakeholder orientation matter? The relationship between stakeholder management models and firm financial performance”, Academy of Management Journal, Vol. 42, pp. 488-506.

Beurden, P. and Gössling, T. (2008), “The worth of values: A literature review on the 
relation between corporate social and financial performance”, Journal of Business Ethics, Vol. 82 No. 2, pp. 407-424.

Bhattacharya, C.B. and Sen, S. (2004), "Doing better at doing good: when, why, and how consumers respond to corporate social initiatives”, California Management Review, Vol. 47, pp. 9-24.

Bird, R., Hall, A.D., Momentè, F. and Reggiani, F. (2007), "What corporate social responsibility activities are valued by the market?”, Journal of Business Ethics, Vol. 76 No. 2, pp. 189-206.

Bitner, M.J., Booms, B.H. and Tetreault, M.S. (1990), “The service encounter: Diagnosing favorable and unfavorable incidents”, Journal of Marketing, Vol. 54 No. January, pp. 71-84.

Boehmer, E., Masumeci, J. and Poulsen, A.B. (1991), "Event-study methodology under conditions of event-induced variance”, Journal of Financial Economics, Vol. 30 No. 2, pp. 253-272.

Bollerslev, T. (1986), “Generalized autoregressive conditional heteroskedasticity”, Journal of Econometrics, Vol. 31, pp. 307-327.

Brammer, S. and Millington, A. (2008), “Does it pay to be different? An analysis of the relationship between corporate social and financial performance”, Strategic Management Journal, Vol. 29, pp. 1325-1343.

Brown, S.J. and Warner, J.B. (1980), “Measuring security price performance”, Journal of Financial Economics, Vol. 8, pp. 205-258.

Brown, S.J. and Warner, J.B. (1985), “Using daily stock returns: The case of event studies”, Journal of Financial Economics, Vol. 14 No. 1, pp. 3-31.

Brown, T.J. and Dacin, P.A. (1997), “The company and the product: Corporate associations and consumer product responses”, Journal of Marketing, Vol. 61 No. 1, pp. 68-84.

Calabrese, A,. and Lancioni, F. (2008), “Analysis of corporate social responsibility in the service sector: Does a strategic path exist?”, Knowledge and Process Management, Vol. 15, pp. 107-125.

Carrol, A.B. (1991a), "The pyramid of corporate social responsibility: Toward the moral management of organizational stakeholders”, Business Horizons, Vol. 34, pp. 39-48.

Carroll, A.B. (1979), “A three dimensional conceptual model of corporate social 
performance”, Academy of Management Review, Vol. 4, pp. 497-505.

Carroll, A.B. (1991b), "Corporate social performance measurement: a comment on methods for evaluating an elusive construct”, in Post, J.E. (Ed.), Research in Corporate Social Performance and Policy, JAI Press Inc, pp. 385-401.

Chun, H. H. and Giebelhausen, M. (2012), "Reversing the green backlash in services: credible competitors help large companies go green”, Journal of Service Management, Vol. 23 No. 3 pp. 400-415.

Clark, J.M., Cornwell, T.B. and Pruitt, S.W. (2009), “The impact of title event sponsorship announcements on shareholder wealth”, Marketing Letters, Vol. 20, pp. 169-182.

Clarkson, M.B. (1995), “A stakeholder framework for analyzing and evaluating corporate social performance”, Academy of Management Review, Vol. 20 No. 1, pp. 92-117.

Coulter, K.S. and Coulter, R.A. (2002), "Determinants of trust in service provider: The moderating role of length of relationship”, Journal of Services Marketing, Vol. 16 No. 1, pp. 35-50.

Dickson, P.R. (1992), “Toward a general theory of competitive rationality”, Journal of Marketing, Vol. 56, pp. 69-83.

Du, S., Bhattacharya, C.B. and Sen, S. (2007), "Reaping relational rewards from corporate social responsibility: The role of competitive positioning”, International Journal of Research in Marketing, Vol. 24 No. 3, pp. 224-241.

Du, S., Bhattacharya, C.B. and Sen, S. (2010), "Maximizing business returns to corporate social responsibility (CSR): The role of CSR communication”, International Journal of Management Reviews, Vol. 12 No. 1, pp. 8-19.

Eisenhardt, K.M. (1989), “Agency theory: An assessment and review”, Academy of Management Review, Vol. 14 No. 1, pp. 57-74.

Eisingerich, A.B., Rubera, G., Seifert, M. and Bhardwaj, G. (2011), “Doing good and doing better despite negative information?: The role of corporate social responsibility in consumer resistance to negative information”, Journal of Service Research, Vol. 14 No. 1, pp. 60-75.

Fama, E.F., Fisher, L., Jensen, M.C. and Roll, R. (1969), “The adjustment of stock prices to new information”, International Economic Review, Vol. 10 No. 1, pp. 1-21.

Farrell, K.A., Karels, G.V., Montfort, K.W. and McClatchey, C.A. (2000), “Celebrity 
performance and endorsement value: The case of Tiger Woods”, Managerial Finance, Vol. 26 No. 7, pp. 1-15.

Freeman, R.E. (1984), Strategic management: A stakeholder approach, Pitman/Ballinger, Boston.

García de los Salmones, M.M., Herrero-Crespo, Á. and Rodríguez del Bosque, I. (2005), "Influence of corporate social responsibility on loyalty and valuation of services", Journal of Business Ethics, Vol. 61, pp. 369-385.

Godfrey, P.C., Merrill, C.B. and Hansen, J.M. (2009), “The relationship between corporate social responsibility and shareholder value: An empirical test of the risk management hypothesis”, Strategic Management Journal, Vol. 30 No. 4, pp. 425-445.

Goll, I. and Rasheed, A.A. (2004), “The moderating effect of environmental munificence and dynamism on the relationship between discretionary social responsibility and firm performance”, Journal of Business Ethics, Vol. 49 No. 1, pp. 41-54.

Gouthier, M.H.J. and Rhein, M. (2011), “Organizational pride and its positive effects on employee behavior”, Journal of Service Management, Vol. 22 No. 5 pp. 633-649.

Griffin, J.J. and Mahon, J.F. (1997), “The corporate social performance and corporate financial performance debate: Twenty-five years of incomparable research”, Business and Society, Vol. 36 No. 1, pp. 5-31.

Grönroos, C. (1994), Marketing y gestión de servicios, Díaz de Santos, Madrid.

Halme, M. and Laurila, J. (2009), "Philanthropy, integration or innovation? Exploring the financial and societal outcomes of different types of corporate responsibility”, Journal of Business Ethics, Vol. 84, pp. 325-339.

Hull, C.E. and Rothenberg, S. (2008), “Firm performance: The interactions of corporate social performance with innovation and industry differentiation”, Strategic Management Journal, Vol. 29, pp. 781-789.

Husted, B.W. (2000), “A contingency theory of corporate social performance”, Business and Society, Vol. 39, pp. 24-48.

Husted, B.W. and Salazar, J.J. (2006), “Taking Friedman seriously: Maximizing profits and social performance”, Journal of Management Studies, Vol. 43 No. 1, pp. 75-91.

Jacoby, J., Olson, J.C. and Haddock, R.A. (1971), "Price, brand name, and product composition characteristics as determinants of perceived quality”, Journal of Applied 
Psychology, Vol. 55 No. 6, pp. 570-579.

Johnston, M.A. (2007), “A review of the application of event studies in marketing”, Academy of Marketing Science Review, Vol. 11 No. 4, pp. 1-31.

Kalaignamam, K., Kushwaha, T., Steenkamp, J.B.E.M. and Tuli, K.R. (2013), “The effect of crm outsourcing on shareholder value: A contingency perspective”, Management Science, Vol. 59 No. 3, pp. 748-769.

Kang, K.H., Lee, S. and Huh, C. (2010), "Impacts of positive and negative corporate social responsibility activities on company performance in the hospitality industry", International Journal of Hospitality Management, Vol. 29 No. 1, pp. 72-82.

Kirmani, A. and Rao, A.R. (2000), "No pain, no gain: A critical review of the literature on signaling unobservable product quality”, Journal of Marketing, Vol. 64 No. April, pp. $66-79$.

Kotler, P. and Lee, N. (2005), Corporate social responsibility-Doing the most good for your company and your cause, John Wiley and Sons, New York.

Lam, S.Y., Shankar, V., Erramili, M.K. and Murthy, B. (2004), "Customer value, satisfaction, loyalty, and switching costs: An illustration from a business-to-business service context”, Journal of the Academy of Marketing Science, Vol. 32 No. 3, pp. 293311.

Lankoski, L. (2009a), “Differential economic impacts of corporate responsibility issues”, Business and Society, Vol. 48 No. 2, pp. 206-224.

Lankoski, L. (2009b), “Cost and revenue impacts of corporate responsibility: Comparisons across sustainability dimensions and product chain stages”, Scandinavian Journal of Management, Vol. 25, pp. 57-67.

Lee, R.P. and Chen, Q. (2009), “The immediate impact of new product introductions on stock price: The role of firm resources and size”, Journal of Product Innovation Management, Vol. 26 No. 1, pp. 97-107.

Lieberman, M.B. and Montgomery, D.B. (1988), “First-mover advantages”, Strategic Management Journal, Vol. 9, pp. 41-58.

Lindgreen, A. and Swaen, V. (2010), “Corporate social responsibility”, International Journal of Management Reviews, Vol. 12 No. 1, pp. 1-7.

Lings, I.N. and Greenley, G.E. (2010), “Internal market orientation and market-oriented 
behaviours”, Journal of Service Management, Vol. 21 No. 3 pp. 321-343.

Luo, X. and Bhattacharya, C.B. (2006), “Corporate social responsibility, customer satisfaction, and market value”, Journal of Marketing, Vol. 70, pp. 1-18.

Mackey, A., Mackey, T.B. and Barney, J.B. (2007), “Corporate social responsibility and firm performance: Investor preferences and corporate strategies”, Academy of Management Review, Vol. 3 No. 32, pp. 817-835.

Maignan, I. and Ferrell, O.C. (2001), “Corporate citizenship as a marketing instrument: Concepts, evidence, and research directions”, European Journal of Marketing, Vol. 35 No. 3/4, pp. 457-484.

Margolis, J.D. and Walsh, J.P. (2003), “Misery loves companies: Rethinking social initiatives by business”, Administrative Sciences Quarterly, Vol. 48, pp. 268-305.

Mattila, A.S. and Hanks, L. (2012), “Antecedents to participation in corporate social responsibility programs”, Journal of Service Management, Vol. 23 No. 5 pp. 664-676.

McWilliams, A. and Siegel, D. (1997), "Events studies in management research: Theoretical and empirical issues”, Academy of Management Journal, Vol. 40 No. 3, pp. 568-592.

McWilliams, A. and Siegel, D. (2000), “Corporate social responsibility and financial performance: Correlation or misspecification?”, Strategic Management Journal, Vol. 21 No. 5, pp. 603-609.

McWilliams, A. and Siegel, D. (2001), "Corporate social responsibility: A theory of the firm perspective”, Academy of Management Review, Vol. 26 No. 1, pp. 117-127.

Mishra, D.P., Heide, J.B. and Cort, S.G. (1998), "Information asymmetry and levels of agency relationships”, Journal of Marketing Research, Vol. 35, pp. 277-295.

Murray, K.B. and Schlacter, J.L. (1990), “The impact of services versus goods on consumers' assessment of perceived risk and variability", Journal of the Academy of Marketing Science, Vol. 18 No. January, pp. 51-65.

Neter, J., Wasserman, W. and Kutner, M. (1985), Applied linear statistical models: Regression analysis of variance and experimental design, Irwin, Homewood, IL.

Nicolau, J.L. (2008), “Corporate social responsibility: Worth-creating activities”, Annals of Tourism Research, Vol. 35 No. 4, pp. 990-1006.

Olcese, A. (2007), La responsabilidad social de la empresa, Real Academia de Ciencias 
Económicas y Empresariales, Barcelona.

Orlitzky, M., Schmidt, F.L. and Rynes, S.L. (2003), "Corporate social and financial performance: A meta-analysis”, Organization Studies, Vol. 24 No. 3, pp. 403-441.

Pava, M.L. and Krausz, J. (1996), “The association between corporate social responsibility and financial performance: The paradox of social cost”, Journal of Business Ethics, Vol. 15 No. 3, pp. 321-357.

Peloza, J. and Shang, J. (2011), "How can corporate social responsibility activities create value for stakeholders? A systematic review", Journal of the Academy of Marketing Science, Vol. 39 No. 1, pp. 117-135.

Porter, M.E. and Kramer, M.R. (2006), “Strategy and society: The link between competitive advantage and corporate social responsibility”, Harvard Business Review, Vol. 84 No. 12, pp. 78-92.

Rao, A.R., Qu, L. and Ruekert, R.W. (1999), "Signaling unobservable product quality through a brand ally”, Journal of Marketing Research, Vol. 36 No. 2, pp. 258-268.

Roll, R. (1988), “R”, The Journal of Finance, Vol. 43 No. 3, pp. 541-566.

Salzmann, O., Ionescu-Somers, A. and Steger, U. (2005), “The business case for corporate social responsibility: Literature review and research options”, European Management Journal, Vol. 23 No. 1, pp. 27-36.

San Martín, S. and Camarero, C. (2005), "Consumer reactions to firm signals in asymmetric relationships”, Journal of Service Research, Vol. 8 No. 1, pp. 79-97.

Scherer, A.G. and Palazzo, G. (2011), "The new political role of business in a globalized world: A review of a new perspective on CSR and its implications for the firm, governance, and democracy”, Journal of Management Studies, Vol. 48 No. 4, pp. 899931.

Sen, S., Bhattacharya, C.B. and Korschun, D. (2006), "The role of corporate social responsibility in strengthening multiple stakeholder relationships: A field experiment”, Journal of the Academy of Marketing Science, Vol. 34 No. 2, pp. 158-166.

Shapiro, C. (1982), “Consumer information, product quality, and seller reputation”, Bell Journal of Economics, Vol. 13 No. 1, pp. 20-35.

Sharpe, W.F. (1963), “A simplified model for portfolio analysis”, Management Science, Vol. 9 No. 2, pp. 277-293. 
Sharpe, W.F. (1964), "Capital asset prices: A theory of market equilibrium under conditions of risk”, The Journal of Finance, Vol. 19 No. 3, pp. 425-442.

Siegel, D.S. and Vitaliano, D.F. (2007), “An empirical analysis of the strategic use of corporate social responsibility”, Journal of Economics and Management Strategy, Vol. 16 No. 3, pp. 773-792.

Simpson, W.G. and Kohers, T. (2002), “The link between corporate social and financial performance: Evidence from the banking industry”, Journal of Business Ethics, Vol. 35, pp. 97-102.

Singh, J. and Sirdeshmukh, D. (2000), "Agency and trust mechanisms in consumer satisfaction and loyalty judgments”, Journal of the Academy of Marketing Science, Vol. 28 No. 1, pp. 150-167.

Stuebs, M.T. and Sun, L. (2009), "Social responsibility and firm efficiency in the business services industry”, paper presented at AAA 2010 Management Accounting Section (MAS), Atlanta, USA.

Sureshchandar, G.S., Rajendran, C. and Anantharaman, R.N. (2001), “A holistic model for total quality service”, International Journal of Service Industry Management, 12 No. 4, pp. 378-412.

Sureshchandar, G.S., Rajendran, C. and Anatharaman, R.N. (2002), “The relationship between service quality and customer satisfaction: A factor specific approach”, Journal of Services Marketing, Vol. 16 No. 4, pp. 363-79.

Taneja, S.S., Taneja, P.K. and Gupta, R.K. (2011), "Researches in corporate social responsibility: A review of shifting focus, paradigms, and methodologies”, Journal of Business Ethics, Vol. 101 No. 3, pp. 343-364.

Ullmann, A. (1985), "Data in search of a theory: A critical examination of the relationships among social performance, social disclosure, and economic performance of U.S. firms”, Academy of Management Review, Vol. 10 No. 3, pp. 540-557.

Vaaland, T.I., Heide, M. and Grønhaug, K. (2008), “Corporate social responsibility: Investigating theory and research in the marketing context”, European Journal of Marketing, Vol. 42 No. 9/10, pp. 927-953.

Vilanova, M., Lozano, J.M. and Arenas, D. (2009), "Exploring the nature of the relationship between CSR and competitiveness”, Journal of Business Ethics, Vol. 87 
No. 1, pp. 57-69.

Vlachos, P.A., Tsamakos, A., Vrechopoulos, A.P. and Avramidis, P.K. (2009), “Corporate social responsibility: Attributions, loyalty, and the mediating role of trust”, Journal of the Academy of Marketing Science, Vol. 37 No. 2, pp. 170-180.

Waddock, S.A. and Graves, S.B. (1997), "The corporate social performance-financial performance link”, Strategic Management Journal, Vol. 18 No. 4, pp. 303-319.

Wang, H., Choi, J. and Li, J. (2008), “Too little or too much? Untangling the relationship between corporate philanthropy and firm financial performance”, Organization Science, Vol. 19 No. 1, pp. 143-159.

Wiles, M.A. (2007), “The effect of customer service on retailers' shareholder wealth: The role of availability and reputation cues”, Journal of Retailing, Vol. 83 No. 1, pp. 19-31.

Zeithaml, V.A. (1981), "How consumer evaluation processes differ between goods and services”, in Donnelly, J.H. and George, W.R. (Eds.), Marketing for Services, Chicago, American Marketing Association, pp. 186-190.

Zeithaml, V.A. and Bitner, M.J. (2000), Services Marketing, McGraw Hill, USA.

Zhang, J.J., Joglekar, N. and Verma, R. (2012), "Pushing the frontier of sustainable service operations management: Evidence from US hospitality industry”, Journal of Service Management, Vol. 23 No. 3 pp. 377-399. 
Table 1. Number of announcements per firm

\begin{tabular}{cc}
\hline & Number of firms \\
\hline Between 20 and 45 & 5 \\
Between 10 and 19 & 12 \\
Between 2 and 9 & 59 \\
One announcement & 41 \\
Total & 117 \\
\hline Average number of announcements per firm: 4.59 \\
\hline
\end{tabular}


Table 2. Abnormal return tests

\begin{tabular}{lccc}
\hline Window & Abnormal returns (\%) & Brown and Warner`s test & Boehmer et al.’s test \\
\hline$(-5,-4)$ & 0.10 & 0.87 & 0.84 \\
$(-5,-3)$ & -0.00 & -0.26 & -0.01 \\
$(-5,-2)$ & 0.04 & 0.31 & 0.47 \\
$(-5,-1)$ & 0.05 & 0.42 & 0.26 \\
$(-5,+5)$ & 0.25 & 1.46 & 1.19 \\
$(+1,+5)$ & 0.26 & $2.01^{\mathrm{a}}$ & $2.03^{\mathrm{a}}$ \\
$(+2,+5)$ & 0.24 & $2.07^{\mathrm{a}}$ & $1.88^{\mathrm{b}}$ \\
$(+3,+5)$ & 0.18 & $2.13^{\mathrm{a}}$ & $1.90^{\mathrm{b}}$ \\
$(+4,+5)$ & 0.21 & $2.55^{\mathrm{a}}$ & $2.40^{\mathrm{a}}$
\end{tabular}


Table 3. Correlation among the independent variables

\begin{tabular}{lccc}
\hline & Service & CSR type & Size \\
\hline Service & 1.00 & & \\
CSR type & 0.188 & 1.00 & \\
Size & 0.278 & 0.197 & 1.00 \\
\hline
\end{tabular}


Table 4. The effect of CSR in the service industry

\begin{tabular}{|c|c|c|}
\hline Variables & Coefficient & $\begin{array}{c}\text { Standard Error } \\
\text { (95\% confidence interval) }\end{array}$ \\
\hline Service & $0.0041^{b}$ & $\begin{array}{c}0.0017 \\
(0.0016-0.0018)\end{array}$ \\
\hline Environment & $0.0052^{\mathrm{b}}$ & $\begin{array}{c}0.0022 \\
(0.0021-0.0023)\end{array}$ \\
\hline Responsible labor relationships & $0.0081^{\mathrm{b}}$ & $\begin{array}{c}0.0040 \\
(0.0038-0.0042)\end{array}$ \\
\hline Social action & 0.0029 & $\begin{array}{c}0.0024 \\
(0.0023-0.0025)\end{array}$ \\
\hline Good corporate governance & $0.0081^{\mathrm{a}}$ & $\begin{array}{c}0.0029 \\
(0.0027-0.0031)\end{array}$ \\
\hline Informative transparency & 0.0055 & $\begin{array}{c}0.0035 \\
(0.0033-0.0037)\end{array}$ \\
\hline Firm size & -0.0041 & $\begin{array}{c}0.0221 \\
(0.0209-0.0234)\end{array}$ \\
\hline Constant & -0.0033 & $\begin{array}{c}0.0018 \\
(0.0017-0.0019)\end{array}$ \\
\hline $\begin{array}{l}\text { R-squared } \\
\text { F-statistic }\end{array}$ & & \\
\hline
\end{tabular}

Note. ${ }^{a} p<.01 ;{ }^{b} p<.05$

\footnotetext{
${ }^{1}$ This low R-squared is not an exception in regression models that use cumulative abnormal returns as dependent variable, in particular (see for example, Farrell et al. 2000; Clark, Cornwell, and Pruitt 2009), and when modeling the excess returns of publicly traded stocks, in general (Roll 1988). At any rate, note that the primary objective of the regression analysis is not to develop a model to predict stock market return, but to analyze the relationship between the types of CSR actions and the firm performance, so the value of Rsquared is less relevant. The important question is that, from the efficient market hypothesis, the abnormal returns employed in this model, reflect the value that the firm may gain through CSR activities.
} 
Table 5. Number of announcements and abnormal returns by CSR Type

\begin{tabular}{lccccc}
\hline & \multicolumn{2}{c}{$\begin{array}{c}\text { Number of } \\
\text { announcements }\end{array}$} & \multicolumn{2}{c}{$\begin{array}{c}\text { Abnormal returns } \\
\text { (AR) }\end{array}$} & $\begin{array}{c}\text { Statistical differences in the } \\
\text { abnormal returns of the event } \\
\text { window (t-test) }\end{array}$ \\
\hline $\begin{array}{l}\text { Environment } \\
\begin{array}{l}\text { Responsible labor } \\
\text { relationships }\end{array}\end{array}$ Goods $^{\text {Services }}$ & Services & Goods & $2,166^{\mathrm{a}}$ \\
$\begin{array}{l}\text { Social action } \\
\text { Good corporate }\end{array}$ & 14 & 56 & 0.0053 & 0.0018 & $1,666^{\mathrm{b}}$ \\
governance & 49 & 70 & 0.0096 & 0.0015 & 0.437 \\
$\begin{array}{l}\text { Informative transparency } \\
\text { Philanthropic sponsorship }\end{array}$ & 20 & 34 & 0.0102 & 0.0017 & $1.691^{\mathrm{b}}$ \\
\hline $\begin{array}{l}\text { Total announcements/ } \\
\text { Average ARs }\end{array}$ & 28 & 103 & 0.0003 & -0.0036 & -0.141 \\
\hline
\end{tabular}

Note. ${ }^{a} p<.05 ;^{b} p<.1$ 